ISSN:2656-4270 (Online) 1410-4466 (Print)

Accredited by Ministry of Research, Technology, and Higher Education with the ranking of Sinta (S4) SK NO.28/E/KPT/2019, 26th September 2019
Buletin Penelitian Sosial Ekonomi Pertanian Fakultas Pertanian Universitas Haluoleo

2021:23(1):44-50

http://ojs.uho.ac.id/index.php/sosek

doi: http://dx.doi.org/10.37149/sosek.v23i1.16940

\title{
GREEN SUPPORT CAPACITY FOR LIVESTOCK FEED AND YIELD OF OIL PALM PLANTATION IN WATUBANGGA SUB DISTRICT KOLAKA DISTRICT
}

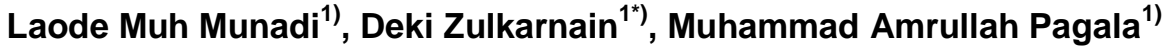 \\ ${ }^{1}$ Universitas Halu Oleo Kendari 93232 Southeast Sulawesi Indonesia \\ ${ }^{*}$ Corresponding author: deki.zulkarnain@uho.ac.id
}

To cite this article:

Munadi, L., Zulkarnain, D., \& Pagala, M. (2021). Green Support Capacity for Livestock Feed and Yield of Oil Palm Plantation in Watubangga Sub District Kolaka District. Buletin Penelitian Sosial Ekonomi Pertanian Fakultas Pertanian Universitas Haluoleo, 23(1), 44 - 50. doi:http://dx.doi.org/10.37149/bpsosek.v23i1.16940

Received: February 28, 2021; Accepted: April 29, 2021; Published: April 30, 2021

\begin{abstract}
This research aims to determine the support of greenery and the results of oil palm plantations as feed for Balinese cattle in Watubangga Sub District. The research method is done by observing the green potential of animal feed. Samples were obtained from the tiling of fodder greens. The research material is a group of grasses, pods, riddles, and the results of oil palm plantations. The research method analyzes weed dominance's carrying capacity and summed dominant ratio (SDR) in a specific area. The results showed nine types of greenery, two types of pods, two types of technical puzzles, and four types of plantation results as a source of livestock feed in Watubangga Sub District. The production of green dried material can meet the needs of 255.33 livestock units, and the effects of oil palm can meet the consumption needs of Balinese cattle 351,516 livestock units.
\end{abstract}

Keywords: Balinese cattle; feed; holding capacity

\section{INTRODUCTION}

The greenery of livestock feed and the results of oil palm plantations is one of the potential feed sources for the development of Balinese cattle. This is supported by the availability of animal feed derived from the type of greenery from plantation plantations and the results of oil palm plantations. Every day ruminants need more than $60 \%$ of the greens to be consumed, both in fresh and dried form. The type of ruminant livestock that has the highest green consumption is one of the Balinese cattle. Crops integrated with cattle can utilize follow-up products and crop by-products (crop residues) for animal feed and vice versa. Cattle can provide organic fertilizer raw materials as a source of nutrients needed by plants (Dewi et al., 2019). The direct benefit of the integration of cattlefood crops is the increase in income of livestock farmers from the sale of cattle and corn. The indirect benefit is improving soil quality due to the provision of manure (Sun et al., 2019). Using waste as an organic fertilizer in the crop-livestock complement system has been shown to increase farmers' productivity and income and reduce production costs (Holland, 2020). On the other hand, organic agricultural products have a brighter prospect than agricultural products loaded with organic matter. Therefore, farmers should implement a system of crop-livestock complementation.

Viewed from the point of view of resilience and security of land fertility, the weak point of the development of oil palm plantations lies in the development of people's oil palm plantations (Tohiran et al., 2019). Oil palm plants that grow in less fertile areas have low productivity levels and are very vulnerable to plant disease pests (Pérez-Gutiérrez \& Kumar, 2019). It is necessary to implement affordable technology by the people's oil palm plantations and effectively maintain the fertility of their plantation land (Umar, 2016). Seeing that these conditions are essential to discriminate the community, it is necessary to develop resource management to simultaneously stimulate economic growth while conducting conservation efforts on environmental resources (Utomo \& Widjaja, 2012). One of them is oil palm and cattle farming (Syarifuddin, 2011). Land use optimization has become an essential issue in Indonesia. Economic development that utilizes land has taken place since before Indonesia's independence for forest product production activities, plantation commodity production, 
mining, and other types of industries (Yamin et al., 2010). The reduction of forest area in Indonesia has been accelerating since the increase in economic activity with large-scale land use.

The integration of cattle with oil palm plantations in the agribusiness system and business was developed with the Low External Input Agricultural System (LEISA) approach, where there is a dependence between crop and livestock activities. The results of oil palm crops and the effects of oil palm processing waste have the opportunity to be used as cattle feed. At the same time, livestock manure and feed waste and harvest products that can not be used for dinner can be decomposed into compost as a provider of nutrients to increase land fertility (Idris et al., 2009).

Opportunities for developing cut cattle in an integrated manner by utilizing greenery in grass and legumes to cover the ground, garden waste such as palm fronds, and crude palm oil (CPO) processing waste as a feed source (Akbar, 2007). Cattle productivity is relatively low, among others, due to high feed costs and low reproductive efficiency. One of the efforts to overcome this is applying the palm-cow integration system, which allows organic fertilizer and optimal land use (Syarifuddin, 2011). At present, the palm-cow integration system is still very limited in its development (Martin et al., 2016).

The population of Balinese cattle in Watubangga Sub District each year has experienced a relatively good increasing trend. In 2016, the people of Balinese cattle in Watubangga Sub District amounted to 8,173 heads. In 2017 , the cattle population increased with the number cattle population of 8,492, and in 2018 amounted to 8,522 crowns (Central Statistics Agency of Kolaka District, 2019).

The population is still relatively low compared to some other districts in Southeast Sulawesi. Watubangga subdistrict has considerable potential for the development of Balinese cattle. This subdistrict still has many vacant lands that can be used as ruminant livestock development land, one of which is oil palm plantations. The community of farmers in Watubangga Subdistrict developed a cattle breeding business by utilizing greenery in open grass, pods, taking puzzles, some superior grasses, and plantations. One of the main obstacles in supporting the success of Balinese cattle development is the production of greens and the effects of oil palm plantations to meet the needs of animal feed and the ability of the region to accommodate the number of livestock. Based on these thoughts, a study was conducted to analyze the green storage capacity and the results of oil palm plantations as Balinese cattle feed in Watubangga Sub District.

\section{MATERIALS AND METHODS}

The material in the research is plantation land as a source of fodder and oil palm processing industry. The study was conducted in Watubangga Sub District March-April 2019 in Kolaka District with 414.50 Hectares of oil palm plantations. The tools used are GPS (Global Positioning System), digital camera, roll meter, compass, and stationery. While the materials used in the oil palm plantation area are questioner, quadrant measuring $1 \mathrm{~m} \times 1 \mathrm{~m}$, tropical green e-book, machete, scissors, large size plastic, newspaper, and writing stationery. While the materials used are natural feed vegetation and the results of oil palm plantations. The method of data collection is done by tiling. The determination of the plot is done by dividing the oil palm plantation spread into five parts diagonally by considering the contours of the land, plant conditions, and ease of reach (Infitria and Khalil, 2014).

The calculation for the analysis of green carrying capacity by using weed vegetation analysis with the formula summed dominance ratio (SDR), which can describe the dominance of weeds in a particular area in controlling the growing means obtained from the amount of Absolute Density (KM), Absolute Frequency (FM), Density Relative (KN), Relative Frequency (FN), and Significant Value (NP). Density is calculated in individual units (Moenadir, 1993). Meanwhile, for plantation follow-up results were analyzed based on the number of oil palm plantation follow-up production in each month, which was converted based on dry matter (BK) with the assumption of plant population of 130 trees/ha, frond production 22 fronds/tree/year, frond weight $7 \mathrm{~kg}$, leaf weight per fronds $0.5 \mathrm{~kg}$, empty bunches $23 \%$ of TBS (Diwyanto, et al., 2004), Palm oil production 4 tons/ha/year (Liwang, 2003), Each $1,000 \mathrm{~kg}$ of TBS produces $250 \mathrm{~kg}$ of palm oil, $294 \mathrm{~kg}$ of mud palm, $180 \mathrm{~kg}$ of noticeable fiber, and $35 \mathrm{~kg}$ of oil palm husks (Jalaludin et al., 1991).

\section{RESULTS AND DISCUSSION}

Greenery is the primary source of feed for ruminant livestock. Various efforts to increase livestock production to meet the needs of animal protein sources will be complicated to achieve when the availability of green feed is not commensurate with the requirements of existing livestock. Feed is an essential factor in cattle farming, both green and concentrated. Continuity of feed supply dramatically determines the success of cattle farming because the cows are in the barn all the time. 
Livestock feeding greens used by ruminant livestock are mostly grasses, so grasses play an important role in feed preparation and have been commonly used by breeders in large numbers.

\section{Availability of Livestock Feed Greens}

The research results show nine types of grass, two types of pods, and two types of puzzles as livestock feed in Watubangga Sub District. Among grass types, Among others are Eleusine indica (L) Gaertn, Axonopus compress (SW), P. Beauv, Braehiaria mutica (Forsk.) Stapf, Ischaemum muticum (L), Cyrtococcum acerencens, Digitaria cilliaris, Ischaemum timorese Kunth, Pennisetum purpureum, Pennisetum purpureum cylindica. Meanwhile, the type of pod is Alysicarpus vaginalis (L.) DC. and Dismodium triflorum (L.) DC. More details are presented in Table 1.

Table 1. Green livestock feed at the research site

\begin{tabular}{cll}
\hline No & \multicolumn{1}{c}{ Local Name } & \multicolumn{1}{c}{ Latin Name } \\
\hline 1. & The Grasses & Poaceae/Graminae \\
& a. Bone Grass & Elausine indica (L) Gaertn \\
& b. Bitter Jakut Grass & Axonopus compresus (SW) P. Beauv \\
& c. Malela grass & Braehiaria mutica (Forsk.) Stapf \\
d. Copper grass & Ischaemum muticum (L) \\
e. Fish Egg Grass & Cyrtococcum acerencens \\
f. $\quad$ Finger Grass & Digitaria Cilliaris \\
g. Ischaemum & Ischaemum timorense kunth \\
h. Elephant Grass & Pennisetum purpureum \\
i. Weed grass & Imperata cylindical \\
\hline 2. & Riddles & Cyperaceae \\
\hline & a. Farm Puzzle & Cyperus rotundus L. \\
& b. Udel Udelan & Cyperus kyllingia \\
\hline 3. The Nuts & Leguminaceae \\
\hline & a. Alysicarpus & Alysicarpus vaginalis (L.) DC. \\
b. Jakut Jeram & Dismodium triflorum (L.) DC. \\
\hline
\end{tabular}

Source: Primary Data Analysis, 2019.

\section{Availability of Feed from Oil Palm Plantation}

The results of the oil palm plantation industry are categorized into seven sections. Oil palm fronds, oil mud, oil palm kernels, oil palm leaves, fiber, empty bunches, and oil palm stems. Oil palm fronds are obtained from pruning done routinely once every six months. At the same time, palm mud is a follow-up produced in the process of squeezing palm fruit. Bungkil core oil palm is one of the results of the oil palm industry, where the production is relatively abundant. Therefore, efforts to use this follow for feed have also been made as a source of energy or protein. In processing through feed technology, one is fermentation (Wan Zahari et al., 2003). Perched fiber results from palm oil extraction with nutrient content and digestive value of $24-30 \%$ or lowers so that its use has not been widely recommended (Diwyanto et al., 2004). Empty oil palm bunches (TKS) are followed by oil palm mills (PKS), accounting for about $55-58 \%$ of fresh fruit bunches.

\section{Composition and Quality of Feed from Oil Palm Plantation}

The composition and quality of the results of oil palm plantations showed that palm fronds Dry Material (BK) content of $26.07 \%$ and Ash Content of $5.10 \%$ with a total Crude Protein of $3.07 \%$. However, the palm fronds have a high enough Gross Fiber (SK) of $50.94 \%$, so that it requires special treatment in the process of feeding livestock. Then on the palm fronds have Gross Fat (LK) only $1.07 \%$. Meanwhile, for total carbohydrate (BETN), 39.82\% had a calcium composition of $0.96 \%$ phosphorus (P) content of $0.08 \%$.

Palm mud is the result of oil palm plantations produced in squeezing palm fruit to make crude palm oil with a dry matter of $24.06 \%$. Meanwhile, palm mud ash has a content of $14.40 \%$ and crude protein $15.58 \%$. However, palm mud has crude fiber with $35.8 \%$ and carbohydrates with $16.36 \%$. Palm mud is one of the excellent alternative feeds for the development of Balinese cattle because it has $1.08 \%$ calcium and $0.25 \%$ phosphorus. Bungkil oil palm core is an oil palm core that has undergone the process of extraction and drying. In addition, oil palm kernels can be used as livestock feed. This oil palm kernel is meant in concentrate feed or reinforcement feed with dry matter $91.83 \%$ then for ash content of $4.14 \%$, crude protein 16.33, natural fiber $36.68 \%$, crude fat 6.49 , carbohydrates 28.19 , calcium $0.56 \%$, and phosphorus 0.84 . 
The crude fiber content of oil palm is quite high, especially the leaves, which is $21.52 \%$. The crude protein content of palm leaves is quite good, which is $14.12 \%$. The dry material has $46.18 \%$, ash content of $13.40 \%$, crude fat $4.37 \%$, carbohydrates 46.59 , calcium $0.84 \%$ and phosphorus $0.17 \%$. Oil palm has an empty bunch that is the remnants of fresh oil palm bunches that have been taken advantage of the fruit flesh. This empty bunch of oil palm can be used as something useful, among others, as a biofuel fuel in the form of bioethanol and can also be used as compost fertilizer for plants and as animal feed. However, the empty bunches in oil palm plantations have a high enough dry matter that requires processing before feeding livestock. As for the dry material in the empty bunch, it is $92.10 \%$, ash content $7.89 \%$, crude protein $3.70 \%$, crude fiber $47.93 \%$, crude fat $4.70 \%$, calcium $0.24 \%$ and phosphorus $0,04 \%$. The Composition and Quality of Feed from Oil Palm Plantation are presented in Table 2.

Table 2. Composition and quality of oil palm feed

\begin{tabular}{lrrrrrrrc}
\hline Palm Side Ingredients/ & \multicolumn{1}{c}{ BK } & \multicolumn{1}{c}{ Abu } & \multicolumn{1}{c}{ PK } & SK & \multicolumn{1}{c}{ LK } & BETN & Ca & P \\
\cline { 2 - 8 } \multicolumn{1}{c}{$\%$} & \multicolumn{1}{c}{$\%$} & \multicolumn{1}{c}{$\%$} & \multicolumn{1}{c}{$\%$} & $\%$ & $\%$ & $\%$ \\
\hline Palm fronds & 26,07 & 5,10 & 3,07 & 50,94 & 1,07 & 39,82 & 0,96 & 0,08 \\
Palm mud & 24,06 & 14,40 & 15,58 & 35,8 & 14,78 & 16,36 & 1,08 & 0,25 \\
Bungkil Inti Sawit & 91,83 & 4,14 & 16,33 & 36,68 & 6,49 & 28,19 & 0,56 & 0,84 \\
Oil Palm Leaves & 46,18 & 13,40 & 14,12 & 21,52 & 4,37 & 46,59 & 0,84 & 0,17 \\
Empty Bunch & 92,10 & 7,89 & 3,70 & 47,93 & 4,70 & - & 0,24 & 0,04 \\
\hline
\end{tabular}

Source: Nurhayu et al., 2015

\section{Summed Dominance Ratio (SDR) Livestock Feed Greens}

The density of vegetation at the research location in Watubangga Sub District gives the impression that the dominance of weeds is dominated by Elausine indica (L) Gaertn with an SDR value of $2.97 \%$. For Axonopus compresus (SW), P. Beauv has an SDR value of $13.60 \%$ with a harvesting area of 70.44 ha. In addition, for other types of greenery such as Braehiaria mutica (Forsk.) Stapf has an SDR value of $1.70 \%$ with a harvesting area of 8.80 ha. The variety of greenery in Ischaemum muticum (L) has an SDR of 2.34 with $12.11 \mathrm{Ha}$. The type of greenery found in the oil palm plantation area is different so that calculating the value of SDR on each plant has a difference. Summed Dominance Ratio (SDR) of oil palm plantations in Watubangga Sub District is presented in Table 3.

Table 3.Summed Dominance Ratio (SDR) of Watubangga Sub District

\begin{tabular}{|c|c|c|c|}
\hline Grass Type (Latin) & $\operatorname{SDR}(\%)$ & Area $(\mathrm{Ha})$ & Wide harvest \\
\hline Elausine Indica (L) Gaertn & 2,97 & 414.50 & 15,41 \\
\hline Axonopus Compresus (SW) P. Beauv & 13,60 & 414.50 & 70,44 \\
\hline Braehiaria Mutica (Forsk.) Stapf & 1,70 & 414.50 & 8,80 \\
\hline Ischaemum Muticum (L) & 2,34 & 414.50 & 12,11 \\
\hline Cyrtococcum Acerencens & 1,70 & 414.50 & 8,80 \\
\hline Digitaria Cilliaris & 6,16 & 414.50 & 31,92 \\
\hline Ischaemum Timorense Kunth & 1,70 & 414.50 & 8,80 \\
\hline Pennisetum Purpureum & 5,10 & 414.50 & 26,41 \\
\hline Imperata Cylindical & 0,42 & 414.50 & 2,20 \\
\hline Cyperus Rotundus L. & 2,97 & 414.50 & 15,41 \\
\hline Cyperus Kyllingia & 2,76 & 414.50 & 14,31 \\
\hline Alysicarpus Vaginalis (L.) DC. & 5,74 & 414.50 & 29,72 \\
\hline Dismodium Triflorum (L.) DC. & 2,12 & 414.50 & 11,01 \\
\hline Total & 49,29 & & 255,33 \\
\hline
\end{tabular}

Source: Primary Data Analysis, 2019

\section{Green Livestock Feed Capacity}

Prawiradiputra (2011) cit. Pomolango et al., (2016) stated that feed is one of the determining factors of good and impaired growth of cattle and goats. Feed for cattle is one of the problems often faced by farmers (Alfian et al., 2012; Nugraha et al., 2013; Salendu and Elly, 2013).

The results showed that the holding capacity of Watubangga Sub District for each type of grass has a different holding capacity according to the area of harvesting, such as Eleusine indica (L.) Gaertn has a livestock holding capacity of 66,200 livestock units. As for the green type Axonopus compresus (SW.) P. Beauv. Has a total livestock capacity of 31,593 livestock units. This indicates that 
each type of grass in Watubangga Sub District has a different holding capacity. The green and livestock feed capacity of the oil palm plantation area of Watubangga subdistrict is presented in Table 4.

Table 4. Green livestock feed capacity

\begin{tabular}{|c|c|c|c|c|c|c|}
\hline Green type & $\begin{array}{l}\text { Harvest } \\
\text { Area (ha) }\end{array}$ & $\begin{array}{c}\text { Production } \\
\text { (BK/Kg/ } \\
\text { Year) }\end{array}$ & $\begin{array}{c}\text { Production } \\
\text { (Kg/Ha/ } \\
\text { Year) }\end{array}$ & $\begin{array}{c}\text { Consumption } \\
\text { (BK/Tail/ } \\
\text { Year) }\end{array}$ & $\begin{array}{l}\text { Production } \\
\text { (ton) }\end{array}$ & KTT \\
\hline $\begin{array}{l}\text { Eleusine indica } \\
\text { (L.)Gaertn } \\
\text { Axonopus }\end{array}$ & 15,41 & 6178 & 217,466 & 3285 & 217,47 & 66,200 \\
\hline $\begin{array}{l}\text { compresus (SW.) P. } \\
\text { Beauv. }\end{array}$ & 70,44 & 6178 & 103,605 & 3285 & 103,61 & 31,539 \\
\hline $\begin{array}{l}\text { Brachiaria mutica } \\
\text { (Forsk.) Stapf }\end{array}$ & 8,80 & 6178 & 73,765 & 3285 & 73,77 & 22,455 \\
\hline Imperata cylindrical & 12,11 & 6178 & 79,758 & 3285 & 79,76 & 24,279 \\
\hline $\begin{array}{l}\text { Ischaemum muticum } \\
\text { (L.) }\end{array}$ & 8,80 & 6178 & 55,849 & 3285 & 55,85 & 17,001 \\
\hline $\begin{array}{l}\text { Cyrtococcum } \\
\text { accrencens }\end{array}$ & 31,92 & 6178 & 99,713 & 3285 & 99,71 & 30,354 \\
\hline Digitaria cilliaris & 8,80 & 6178 & 125,661 & 3285 & 125,66 & 38,253 \\
\hline $\begin{array}{l}\text { Ischaemum } \\
\text { timorense kunth }\end{array}$ & 26,41 & 6178 & 53,872 & 3285 & 53,87 & 16,399 \\
\hline $\begin{array}{l}\text { Pennisetum } \\
\text { purpureum }\end{array}$ & 2,20 & 6178 & 15,939 & 3285 & 15,94 & 4,852 \\
\hline $\begin{array}{l}\text { Cyperus rotundus L. } \\
\text { Cyperus kylingia }\end{array}$ & $\begin{array}{l}15,41 \\
14,31\end{array}$ & $\begin{array}{l}6178 \\
6178\end{array}$ & $\begin{array}{l}63,819 \\
63,819\end{array}$ & $\begin{array}{l}3285 \\
3285\end{array}$ & $\begin{array}{l}63,82 \\
63,82\end{array}$ & $\begin{array}{l}19,427 \\
19,427\end{array}$ \\
\hline Alysicarpus vaginalis & 29,72 & 6178 & 125,661 & 3285 & 125,66 & 38,253 \\
\hline Desmodium triflorum & 11,01 & 6178 & 75,804 & 3285 & 75,80 & 23,076 \\
\hline Holding Capacity & 255,33 & & $1,154,73$ & & $1,154,73$ & 351,516 \\
\hline
\end{tabular}

Ha: Hectare; BK: Dry Material; KTT: Livestock Holding Capacity

Source: Primary Data Analysis, 2019.

\section{f. Carrying Capacity of Plantation Results}

The carrying capacity of Watubangga Subdistrict varies based on the number of plantation results that are produced, whether they have undergone industrial processes or not. The type of palm leaf follow-up yield has a total annual follow-up yield of 592,020 wet weight $\mathrm{kg} / \mathrm{year}$ with 272,329 $\mathrm{kg} / \mathrm{year}$ natural dry matter. So that the full carrying capacity for the type of oil palm plantation results in oil palm leaves as many as 83 livestock units, meanwhile, the kind of product in the form of palm mud with dry matter $21,190,269 \mathrm{~kg} /$ year can accommodate 6,451 livestock units/year. This is one of the potential feed sources in meeting livestock feed needs found in oil palm plantations. Meanwhile, for the type of oil palm plantation products in the form of oil palm kernels with dry material in a year, as many as $1,151,920$ can meet the needs of animal feed as many as 351 livestock units. Table 5 shows that the type of oil palm plantation results in empty bunches that can accommodate 15,309 livestock units with $50,290,786 \mathrm{~kg} / \mathrm{year}$ dry matter. Thus, the oil palm plantation industry's total carrying capacity in Watubangga Sub District can accommodate 22,193 livestock units. For carrying capacity based on the results of oil palm plantations are presented in Table 5.

Table 5. Carrying capacity of plantation results

\begin{tabular}{rlrrrrrr}
\hline Land & \multicolumn{1}{|c}{$\begin{array}{c}\text { Follow } \\
\text { Result } \\
\text { Type }\end{array}$} & $\begin{array}{c}\text { Total } \\
\text { Follow -up } \\
\begin{array}{c}\text { Result } \\
\text { (Month/Ha) }\end{array}\end{array}$ & $\begin{array}{c}\text { Total } \\
\text { Follow-up } \\
\text { Results/Year }\end{array}$ & $\begin{array}{c}\text { Results } \\
\text { Following } \\
\text { Wet Weight } \\
\text { (Kg/Year) }\end{array}$ & $\begin{array}{c}\text { Results of } \\
\text { Dry } \\
\text { Material } \\
\text { (Kg/Year) }\end{array}$ & $\begin{array}{c}\text { Feed } \\
\text { Needs } \\
\text { (BK } \\
\text { /Tails/ } \\
\text { Year) }\end{array}$ & KTT \\
\hline 414.50 & $\begin{array}{l}\text { Palm } \\
\text { leaves }\end{array}$ & 53,820 & $1,184,040$ & 592,020 & 272,329 & 3285 & 83 \\
414.50 & $\begin{array}{l}\text { Palm mud } \\
\text { Bungkil Inti }\end{array}$ & $6,458,400$ & $77,500,800$ & $22,785,235$ & $21,190,269$ & 3285 & 6,451 \\
414.50 & Sawit & $3,013,920$ & $36,167,040$ & $1,265,846$ & $1,151,920$ & 3285 & 351 \\
\hline
\end{tabular}


Table 5. Carrying capacity of plantation results

\begin{tabular}{cccccccc} 
Land & $\begin{array}{c}\text { Follow } \\
\text { Result } \\
\text { Type }\end{array}$ & $\begin{array}{c}\text { Follow -up } \\
\text { Result } \\
\text { (Month/Ha) }\end{array}$ & $\begin{array}{c}\text { Total } \\
\text { Follow-up } \\
\text { Results/Year }\end{array}$ & $\begin{array}{c}\text { Results } \\
\text { Following } \\
\text { Wet Weight } \\
\text { (Kg/Year) }\end{array}$ & $\begin{array}{c}\text { Results of } \\
\text { Dry } \\
\text { Material } \\
\text { (Kg/Year) }\end{array}$ & $\begin{array}{c}\text { Feed } \\
\text { Needs } \\
\text { (BK } \\
\text { /Tails/ } \\
\text { Year) }\end{array}$ & KTT \\
\hline 414.50 & $\begin{array}{c}\text { Empty } \\
\text { Bunch }\end{array}$ & $19,805,760$ & $237,669,120$ & $54,663,898$ & $50,290,786$ & 3285 & 15,309 \\
\hline
\end{tabular}

Source: Primary Data Analysis, 2019

\section{CONCLUSIONS}

Green production in the plantation gap there is nine types of grass, two types of pods, two types of puzzles with different Summed Dominance Ratio (SDR) values depending on the dominance of weeds in a particular area in controlling the growing facilities with a total carrying capacity of 351,516 livestock units. The oil palm industry located in Watubangga Sub District can accommodate as many as 22,193 Balinese cattle breeding units.

\section{REFERENCES}

Akbar, S. (2007). Pemanfaatan Tandan Kosong Sawit Fermentasi Yang Dikombinasikan Dengan Defaunasi Dan Protein By Pass Rumen Terhadap Performans Ternak Domba Journal of the Indonesian Tropical Animal Agriculture, 32(2), 80-85.

Alfian, Y., F. I Hermansyah, E. Hardayanto, Utoyo, dan W. P. S. Suprayogi. (2012). Analisis daya tampung ternak ruminansia pada musim kemarau di daerah pertanian lahan kering Kecamatan Semin Kabupaten Gunung Kidul, Tropical Animal Husbandry 1(2) 33-42.

Badan Pusat Statistik Kabupaten Kolaka 2019, Kabupaten Kolaka Dalam Angka. Kabupaten Kolaka.

Dewi, P., Darmawan, S., Didi, R., \& B. Eymal, Demmalino. (2019). Farmers Household Strategy in Land Conversion Dynamics (Case Study of Penrang District, Wajo Regency, South Sulawesi). International Journal of Scientific Research in Science and Technology, January, 278-287. https://doi.org/10.32628/ijsrst196351.

Diwyanto K, Prawiradiputra B., R, \& Lubis D. (2004). Integrasi Tanaman-Ternak Dalam Pengembangan Agribisnis Yang Berdaya Saing Dan Berkelanjutan. Wartazoa, 12(2), 1-8.

Holland, J. (2020). Integrated Farming Systems. Managing Soils and Terrestrial Systems, 4(9), 171175. https://doi.org/10.1201/9780429346255-23.

Idris, N., Fatati, A. H., Studi, P., Ekonomi, S., U. (2009). Kawasan Perkebunan Kelapa Sawit ( Studi Kasus: Kecamatan Sungai Bahar Kabupaten Muaro Jambi). Jurnal Penelitian Universitas Jambi Seri Humaniora, 11(2)1-7.

Infitria \& Khalil. (2014). Studi produksi dan kualitas hijauan di lahan padang rumput UPT peternakan Universitas Andalas Padang. buletin Makanan Ternak. 101(1), 25-33.

Jalaludin, S., Y.W. Ho, N. Abdullah, and H.Kudo. (1991). Strategies for animal improvement in Southeast Asia. In Utilization of Feed Resources in Relation to Utilization and Physiology of ruminants in the Tropics. Trop. Agric.Res, 25(3), 67-76.

Liwang, T. (2003). Palm oil mill effluent management. Burotrop Bull. 19:38.

Martin, G., Moraine, M., Ryschawy, J., Magne, M. A., Asai, M., Sarthou, J. P., Duru, M., \& Therond, O. (2016). Crop-livestock integration beyond the farm level: A review. Agronomy for Sustainable Development, 36(3), 36-53. https://doi.org/10.1007/s13593-016-0390-x

Moenandir, J. (1993). IImu Gulma. Raja GrafindoPersada. hal. 181.

Nugraha, B. D., E. Handayanta, dan E. T. Rahayu. (2013). Analisis daya tampung (carrying capacity) ternak ruminansia pada musim penghujan di daerah pertanian lahan kering Kecamatan Gunung Kidul. Tropical Animal Husdbandry, 2(2), 34-40.

Nurhayu, A. B. L Ishak, \& A. Ella. (2015). Pelepah Dan Daun Sawit Sebagai Pakan Substitusi Hijauan Pada Pakan Ternak Sapi Potong Di Kabupaten Luwu Timur Sulawesi Selatan. Balai Pengkajian Teknologi Pertanian Sulawesi Selatan, 1(3), 108-115.

Pérez-Gutiérrez, J. D., \& Kumar, S. (2019). Simulating the influence of integrated crop-livestock systems on water yield at a watershed scale. Journal of Environmental Management, 239, 385-394. https://doi.org/10.1016/j.jenvman.2019.03.068 
Pomolango, R., Ch. L. Kaunang, dan F. H. Elly. (2016). Analisis produksi limbah tanaman pangan sebagai pakan ternak sapi di Kabupaten Bolaang Mongondow Utara. Zootek Journal, 36(3), 302-311.

Salendu, A. H. S., \& F. H. Elly. (2013). Agroecosystem of coconut-cattle and carrying capacity analysis inLolayan Subdistrict of BolaangMongondow Regency. European Journal of Social Science 40: 549 - 555.

Sun, Z., Guo, Y., Li, C., Cao, C., Yuan, P., Zou, F., Wang, J., Jia, P., \& Wang, J. (2019). Effects of straw returning and feeding on greenhouse gas emissions from integrated rice-crayfish farming in Jianghan Plain, China. Environmental Science and Pollution Research, 26(12), 11710-11718. https://doi.org/10.1007/s11356-019-04572-w

Syarifuddin, H. (2011). Komposisi dan struktur hijauan pakan ternak di bawah perkebunan kelapa sawit. Agrinak, 1(1), 25-30.

Tohiran, K. A., Nobilly, F., Zulkifli, R., Ashton-Butt, A., \& Azhar, B. (2019). Cattle-grazing in oil palm plantations sustainably controls understory vegetation. Agriculture, Ecosystems and Environment, 278, 54-60. https://doi.org/10.1016/j.agee.2019.03.021

Umar, S. (2016). Potensi Perkebunan Kelapa Sawit Sebagai Pusat Pengembangan Sapi Potong Dalam Merevitalisasi dan Mengakselerasi Pembangunan Peternakan Berkelanjutan. Potensi Perkebunan Kelapa Sawit Sebagai Pusat Pengembangan Sapi Potong Dalam Merevitalisasi dan Mengaksele. Prosiding Seminar Nasional Inovasi Teknologi Pertanian, 1282-1292.

Utomo, B., \& Widjaja, E. (2012). Pengembangan Sapi Potong Berbasis Industri Perkebunan Kelapa Sawit. Jurnal Penelitian Dan Pengembangan Pertanian, 31(4), 30920. https://doi.org/10.21082/jp3.v31n4.2012.p

Wan Zahari, M., O. A. Hassan, H.K. Wong \& J.B. Liang. (2003). Utilization of oil palm frondbaseddiet for beef cattle production in Malaysia. Asian-Aust. J. Anim. Sci. 16(4), 625-634.

Yamin, M., Muhakka, \& Abrar, A. (2010). Kelayakan Sistem Integrasi Sapi dengan Perkebunan Kelapa Sawit di Provinsi Sumatera Selatan. Jurnal Pembangunan Manusia, 10(1), 1-21. 